\title{
Vermiconversion of Paper Mill Sludge for Recycling the Nutrients Using Earthworm Eudrilus eugeniae
}

\author{
Nirmala Natarajan and M. Gajendran \\ Research Department of Zoology, Periyar E.V.R. College (Autonomous), Tirichirappalli, Tamil Nadu, India.
}

\begin{abstract}
Pot culture experiments were done to process paper mill sludge mixed with bedding materials (cow dung, pig waste and water hyacinth (Eichhornia crassipes) in the ratio of 25:75, 50:50, and 75:25 using earthworm Eudrilus eugeniae. Totally there were three treatments $\left(T_{1}, T_{2}\right.$ and $\left.T_{3}\right)$ with three replicates for each. Before and after treatments physico-chemical parameters such as $p H, O C, T N, T P$, tot TK, Ca, Zn, Fe and Mn were analysed. There were reduction in $\mathrm{pH}$ and $\mathrm{OC}$ in all vermibeds. On comparison in $T_{2}$ the level of macronutrients such as tot $N$, tot $P$, tot $K$ were found to be high. Micronutrients were high in $T_{2}$. Earthworm biomass and cocoon production were also studied.
\end{abstract}

Keywords: Earthworm, Paper Mill Sludge, Vermicompost, Cocoon, Macronutrients and Micronutrients

\section{Introduction}

Paper industry of India is the $15^{\text {th }}$ largest industry in the world and contributes 5 million dollars to the government's coffer annually. The world paper industry has been registering a growth rate of $2.8 \%$ per annum to meet the growing demand for paper and paperboard which is expected to grow from 300 million tons to 420 million tons by the end of 2010. So much so that the US paper industry the largest in the world recorded 100 million dollars profit in the year 2009 alone. Correspondingly more landfill space will be required or dumping the toxic organic sludge generated by this industry. This will not only severely pollute land and ground water of that area but there will also be a waste of rich carbon resource. Legislation for protection of environment, decreasing landfill space and public awareness have drawn more attention towards alternative strategies for recovery of rich pool of nutrients from such wastes [1].

In India the exotic epigeic species, like Eudrilus eugeniae [2], Perionyx excavatus [3] and Eisenia fetida [4] are being used for vermicomposting. The hazards of using alien species are well known. History is littered with examples of confrontations between indigenous and foreign organisms [5]. The introduction of foreign species has been justified by a few scientists $[6,7]$, though it is extremely unnecessary and undesirable to tamper with local biodiversity [8]. Keeping this in view Eudrilus eugeniae (exotic and local species respectively) were chosen for the comparative study of their potential in vermicomposting of PMS.

Literature clearly indicates that vermicomposting is fast in comparison to traditional aerobic composting (without worms) and gives a product rich in organic matter, N, P, K and other plant nutrients [9, 10]. Vermicomposting is being considered as a potential option in the hierarchy of integrated solid waste management. It involves stabilization of organic material by the joint action of earthworms and microorganisms. Although microbes are responsible for biochemical degradation of organic matter, earthworms are the important drivers of the process by conditioning the substrate and altering the biological activity [11]. However, the processing time and quality of the end product vary according to the composition of the initial mixture being processed [12]. The various industrial wastes which have been vermicomposted and turned into nutrient rich manure include paper waste [1,13], textile mill sludge [14], guar gum industrial waste [15], sugar industry wastes [16], distillery sludge [17], leather industry [18] and beverage industry sludge [12], agro-industrial sludge [19], primary sewage sludge [20], tannery industries [21].

The aim of the present investigation was to vermicompost solid paper mill sludge (PMS) from a paper mill industry using the earthworm species, E.eugeniae. The dried sludge was mixed with bedding materials (cow dung, water hyacinth and pig waste) at different ratios $(25: 75,50: 50$ and 75:25) in order to optimize the waste mixture for better decomposition/mineralization. The changes in physical and chemical parameters of waste materials were measured. Earthworm cocoon production patterns in different waste mixture were also monitored during vermicomposting process.

\subsection{Collection and Culturing of Earthworms}

\section{Materials and Methods}

Eudrilus eugeniae was purchased from Periyar Maniammai University, Thanjavur, and were cultured in the vermicomposting unit of the PG and Research Department of Zoology, Periyar E.V.R College, Tiruchirappalli, India. The Cement tanks using cow dung and leaf litter as culturing material. 


\subsection{Collection of Paper Mill Sludge}

Paper mill sludge (PMS) was collected from the paper mill industry (TNPL, Pugalur, Tamil Nadu, India), containing $67-74 \%$ moisture and was collected in $20 \mathrm{~L}$ plastic containers, dried in the shade on polythene bags to remove excess water while turning daily. Partially dried sludge cake solids were homogenized and shredded.

\subsection{Collection of Cow Dung, Pig Waste and Water Hyacinth}

The cow dung (CD) was obtained from a Parvathi cowshed located in Khajamalai, Tiruchirappalli, Tamil Nadu, India. The pig waste (PW) was collected from a livestock farm located at Tiruchirappalli, Tamil Nadu. The cow dung and pig waste was partially dried in a shed and stored for further experimentations. The water hyacinth (Eichhornia crassipes) plants were collected from infested river Uyyakondan, Tiruchirappalli. The water hyacinth was allowed to dry slightly in sunlight and was chopped into small bits.

\subsection{Experimental Setup}

The experiment was conducted in earthen pots of capacity $2 \mathrm{~kg}$ with a small hole at the bottom. Aerobically treated solid paper mill sludge was slightly dried in air and mixed with bedding materials in different ratios to give different combinations. Bedding materials was air dried and mixed with solid paper mill sludge in different ratios. Experimental beddings were kept in triplicates for each treatment, and the control treatment had the same setup without earthworm. These mixtures were turned over manually every day for 20 days in order to eliminate volatile toxic substances. After 20 days, fifteen clitellated, E.eugeniae were collected from the stock culture and released into different earthen pot containers. The moisture level of substrates was maintained around $70-73 \%$, throughout the study period by periodic sprinkling of adequate quantity of tap water. Containers were placed in a humid and shady place at an ambient temperature $\left(27-28^{\circ} \mathrm{C}\right)$. The important physical and chemical parameters of substrate were measured in all the treatments before the introduction of earthworms and after 80 days. Biological parameters of composting earthworm biomass and cocoon production were studied in vermicomposting subsystem, following the method of Negi and Suthar [22].

\subsection{Chemical Analysis}

The $\mathrm{pH}$ and electrical conductivity (EC) were determined using a water suspension of the vermicompost in the ratio of 1:10 (w/v) after agitating for $30 \mathrm{~min}$ by $\mathrm{pH}$ and electrical conductivity meters, respectively. Organic carbon was determined by the partiall-oxidation method Walkley and Black [23]. Total nitrogen was measured by micro Kjeldahl method [24]. Extractable phosphorous was determined by following Olson's sodium bicarbonate extraction method [25]. Exchangeable elements $(\mathrm{K}, \mathrm{Ca}$ and $\mathrm{Mg}$ ) were determined after extracting the sample using ammonium acetate extractable method [26]. The concentration of micronutrients, i.e. $\mathrm{Cu}, \mathrm{Fe}, \mathrm{Zn}$, and $\mathrm{Mn}$ was determined by following diethylene-triaminepentaacetic acid (DTPA) extraction method, analyzed by Atomic Absorption Spectrophotometer (AAS).

\subsection{Nutrient Quality of Vermicomposted Material}

\section{Results and Discussion}

Vermicomposting had a different treatment on the quality of the waste feedstock after eighty days. The end material was more stabilized, odour free, and dark brown with a high level available nutrients for plant growth. The changes in different physicochemical properties over the period of the experiment were described in Table-1. $\mathrm{pH}$ is an important parameter in the vermicompost for promoting plant growth. There was a decrease in $\mathrm{pH}$ in all the treatments $\left(\mathrm{T}_{1}-\mathrm{T}_{3}\right)$ relative to their initial values during vermicomposting (Table-1). Initially $\mathrm{pH}$ values in different treatments were in range of 6.93, 7.49, and 7.76 in final vermicompost, ranged from 6.73, 7.40 and 7.61. Maximum reduction was recorded in T3, while minimum was recorded in T2. Gupta et al., [27] also reported reduction in $\mathrm{pH}$ during vermicomposting of water hyacinth. Suthar [28] has reported that $12.3 \%$ and $14.7 \%$ reduction in $\mathrm{pH}$ than initial levels in cattle wastes vermicomposting. Elvira et al., [13] concluded that the production of $\mathrm{CO}_{2}$ and organic acids by the combined action of earthworms and microbial decomposition during vermicomposting lowers the $\mathrm{pH}$ of substrate.

The EC of vermicomposts, which were in range of $0.31 \mathrm{dS} \mathrm{m}^{-1}\left(\mathrm{~T}_{2}\right), 0.46 \mathrm{dSm}^{-1}\left(\mathrm{~T}_{1}\right)$ was obtained and $0.47 \mathrm{dSm}^{-1}\left(\mathrm{~T}_{3}\right)$ were the highest than those of the initial waste mixtures (Table -1). This increase may be due to mineralization and consequent formation of ions in different waste mixtures in the presence of earthworms. The maximum increase in EC was recorded in Treatment $3(0.47)$ and minimum in Treatment $1(0.46)$. Deka et al., [29] have reported that earthworms produce organic-mineral compounds by digesting the organic materials as feed and these minerals may accumulate in the final products. It was observed that the organic carbon (OC) decreased from the initial value. Decline in $\mathrm{OC}$ was maximum in $\mathrm{T}_{1}(0.51 \%)$ feed mixture. The percentage decrease in OC was in the order of $T_{1}>T_{3}>T_{2}$. The decrease in OC after vermicomposting indicates organic matter stabilization in the substrate due to combined action of earthworms and soil microorganisms. It has been 
reported that earthworms modify the substrate conditions, which subsequently enhances the carbon losses from the substrates through microbial respiration in the form of $\mathrm{CO}_{2}[30,31]$. Garg and kaushik [14] reported $20-15 \%$ loss of organic carbon in the form of $\mathrm{CO}_{2}$ from different industrial sludge during vermicomposting.

Table -1 Physico-chemical characteristics of paper mill sludge (PMS) in different proportions subjected to vermicomposting (80 days) using the earthworm, Eudrilus eugeniae

\begin{tabular}{|c|c|c|c|c|c|c|c|c|c|}
\hline \multirow{2}{*}{ Name of the Parameter } & \multicolumn{3}{|c|}{$T_{1}(25 \%$ PMS $)$} & \multicolumn{3}{|c|}{$T_{2}(50 \%$ PMS $)$} & \multicolumn{3}{|c|}{$\mathrm{T}_{3}(75 \%$ PMS $)$} \\
\hline & Control & Initial & Final & Control & Initial & Final & Control & Initial & Final \\
\hline $\mathrm{pH}$ & 7.29 & 7.76 & 7.61 & 6.47 & 7.49 & 7.40 & 6.87 & 6.93 & 6.73 \\
\hline $\mathrm{EC}\left(\mathrm{dSm}^{-1}\right)$ & 0.14 & 0.39 & 0.46 & 0.30 & 0.14 & 0.31 & 0.12 & 0.15 & 0.47 \\
\hline Organic Carbon $(\%)$ & 0.52 & 1.16 & 0.51 & 0.76 & 0.87 & 0.60 & 0.65 & 1.19 & 0.54 \\
\hline Total Nitrogen $(\mathrm{kg} / \mathrm{ha})$ & 210 & 214.6 & 314 & 212 & 248 & 313 & 307 & 205 & 272 \\
\hline Total Phosphorus (kg/ha) & 15.3 & 16.4 & 18.4 & 14.6 & 18 & 21.4 & 13 & 10.9 & 23 \\
\hline Total Potassium(kg/ha) & 234 & 290 & 376 & 276 & 216 & 364 & 304 & 300 & 335.6 \\
\hline Calcium (\%) & 4.8 & 8.5 & 10.7 & 6.3 & 6.5 & 12.9 & 9.3 & 7.1 & 9.8 \\
\hline Megnesium (\%) & 2.6 & 4.2 & 6.0 & 2.9 & 4.3 & 6.4 & 4.9 & 3.6 & 5.1 \\
\hline $\operatorname{Iron}(\mathrm{ppm})$ & 9.41 & 9.96 & 13.47 & 12.6 & 8.29 & 29.4 & 11.0 & 11.4 & 16.31 \\
\hline Zinc (ppm) & 0.22 & 0.49 & 0.79 & 0.11 & 0.16 & 0.18 & 0.11 & 0.05 & 0.14 \\
\hline Copper(ppm) & 0.43 & 0.47 & 1.01 & 0.24 & 0.23 & 0.43 & 0.51 & 0.29 & 0.56 \\
\hline Manganese(ppm) & 0.16 & 0.11 & 0.53 & 0.32 & 0.39 & 0.99 & 0.51 & 0.15 & 0.75 \\
\hline
\end{tabular}

Increase in Total Nitrogen in all the vermibeds were shown in Table -1 . The final $\mathrm{N}$ content was $314-272 \mathrm{~kg} / \mathrm{ha}\left(\mathrm{T}_{1}-\mathrm{T}_{3}\right)$ in vermicomposted substrate. Maximum total $\mathrm{N}$ content (as compared to the initial level) was in observed in $T_{1} 314 \mathrm{~kg} /$ ha followed by $T_{2} 313 \mathrm{~kg} / \mathrm{ha}$, and minimum nitrogen content was recorded in $T_{3}$ $272 \mathrm{~kg} / \mathrm{ha}$. The increase was higher in the vermibeds than in experimental controls (Table-1). The present data clearly suggested that nitrogen increase in vermicomposted material was directly related to the physico-chemical properties of the initial substrates. $\mathrm{N}$ mineralization was more in beddings which contained a higher or equal proportion of bedding materials. Bedding materials modify the physical structure of waste and also accelerate the waste mineralization rate in vermibeds. Benitez et al., [32] suggested that hydrolytic enzyme production plays an important role in $\mathrm{C}$ and $\mathrm{N}$ cycle in waste decomposition system and was drastically influenced by the availability of easily degradable organic compounds (cattle dung) in vermibeds. Most other reports on vermicomposting $[13,19,33]$ have reported a higher $\mathrm{N}$ increase at the end.

Phosphorus $(\mathrm{P})$ content in vermicomposted material was higher than in control treatment at the end. The highest $\mathrm{P}$ content was recorded in $\mathrm{T}_{3}(23 \mathrm{~kg} / \mathrm{ha})$ followed by $\mathrm{T}_{2}(21.4 \mathrm{~kg} / \mathrm{ha})$ and $\mathrm{T}_{1}(18.4 \mathrm{~kg} / \mathrm{ha})$. The earthworm affects phosphorus mineralization in wastes if reared for longer periods [17]. Phosphorus mineralization varied significantly among different vermibeds possibly due to quality and proportion of bedding materials in feedstock. According to Lee [34], if organic matter passes through the gut of the earthworm, it results in some amount of phosphorus being converted that are highly essential for plants. The release of phosphorus in available form is performed partly by earthworm gut phosphatases, and further release of $\mathrm{P}$ might be attributed to the P-solubilizing microorganisms present in worm casts. The difference among vermireactors for P mineralization rate could be due to different chemical structure of substrate material [17].

Exchangeable Potassium $(\mathrm{K})$ content in ready vermicompost was higher in (Table-1) than the initial substrate material. The highest $\mathrm{K}$ content was recorded in $\mathrm{T}_{1}$ (376) and $\mathrm{T}_{2}$ (364), respectively. Minimum $\mathrm{K}$ content was noticed in $\mathrm{T}_{3} 335.5 \mathrm{~kg} / \mathrm{ha}$, when compared to initial and control. However, when organic waste passes through the gut of worm the some quantity of organic minerals are then converted into more available forms through the action of enzymes produced by gut associated microflora. Thus vermicomposting plays an important role in microbial-mediated nutrient mineralization in wastes. The results of this study agree with previous reports that the vermicomposting process accelerates the microbial populations in waste and subsequently enriches the end product with more available forms of plant nutrients [28].

The calcium $(\mathrm{Ca})$ and magnesium $(\mathrm{Mg})$ concentration were found to be maximum in $12.9 \%\left(\mathrm{~T}_{2}\right)$ and $6.4 \%\left(\mathrm{~T}_{2}\right)$ respectively. The increase in $\mathrm{Ca}$ was high in vermibeds that had a higher proportion of bedding materials. Earthworm drives the mineralization process efficiently and transforms a large proportion of $\mathrm{Mg}$ from bind to free form which results higher concentration of $\mathrm{Mg}$ in the vermicompost. The solid paper mill sludge contained appreciable amounts of micronutrients. The concentration of $\mathrm{Fe}, \mathrm{Zn}, \mathrm{Cu}$ and $\mathrm{Mn}$ in sludge recorded were $29.4 \mathrm{ppm}, 0.79 \mathrm{ppm}, 1.01 \mathrm{ppm}$ and $0.75 \mathrm{ppm}$ respectively. The release of plant available forms of trace elements in vermicompost could be due to mineralization of partially digested worm faecal by detritus communities, such as bacteria and fungi. In general, earthworm fragments and modifies the physical structure of ingested wastes through muscular actions of foregut and consequently increases the surface area for microbial action $[28,35]$. Such biological coordination results in high level of extractable or available trace elements in ready vermicompost. 


\subsection{Biomass and Cocoon Production by $E$. eugeniae in Different Treatments}

E. eugeniae showed excellent patterns of biomass gain and cocoon productions in all vermibeds during the vermicomposting experimentation. Paper mill sludge proved to be good for earthworm biomass but it negatively affected reproduction of $E$. eugeniae. Maximum worm biomass was observed in $T_{3}$ on 60th day, which was followed by $T_{2}$ and $T_{1}$. The worm biomass started declining in $T_{1}$ and $T_{2}$ mixture after 60th day (Fig.2), moreover, compost started granulating on the surface and it also indicated exhaustion of nutrients in the mixture. Neuhauser et al. [36] and Edwards et al., [9] reported that population density of worms per unit volume or weight of feed was important in affecting the rate of growth and reproduction.

Worm biomass, however, increased with the increasing proportion of paper mill sludge in the feed mixture but it corresponded with a very low rate of production of cocoons. Seems that the energy otherwise to be used for reproduction was diverted towards weight gain by the worms. This gets corroborated by the findings of that in paper sludge earthworms had more biomass and low reproductive rate. Low level of nitrogen in paper mill sludge is considered a limiting factor for the growth of worms [37].

Cocoon production was started and monitored from second week in $75 \% \mathrm{BM}+25 \% \mathrm{PMS}, 50 \% \mathrm{BM}+$ $50 \%$ PMS and 25BM $+75 \%$ PMS feed mixtures and in fourth week in the rest of the feeds except $50 \% \mathrm{CD}+$ $50 \%$ PMS (fifth week). Cocoon production fluctuated considerably with time. Initially cocoon production rate was high. This rate decreased after eighth week and then approximately constant. Since cocoon production is highly dependent on the food availability, which explains much fluctuation.

Fig.1 Number of cocoons in various paper mill sludge

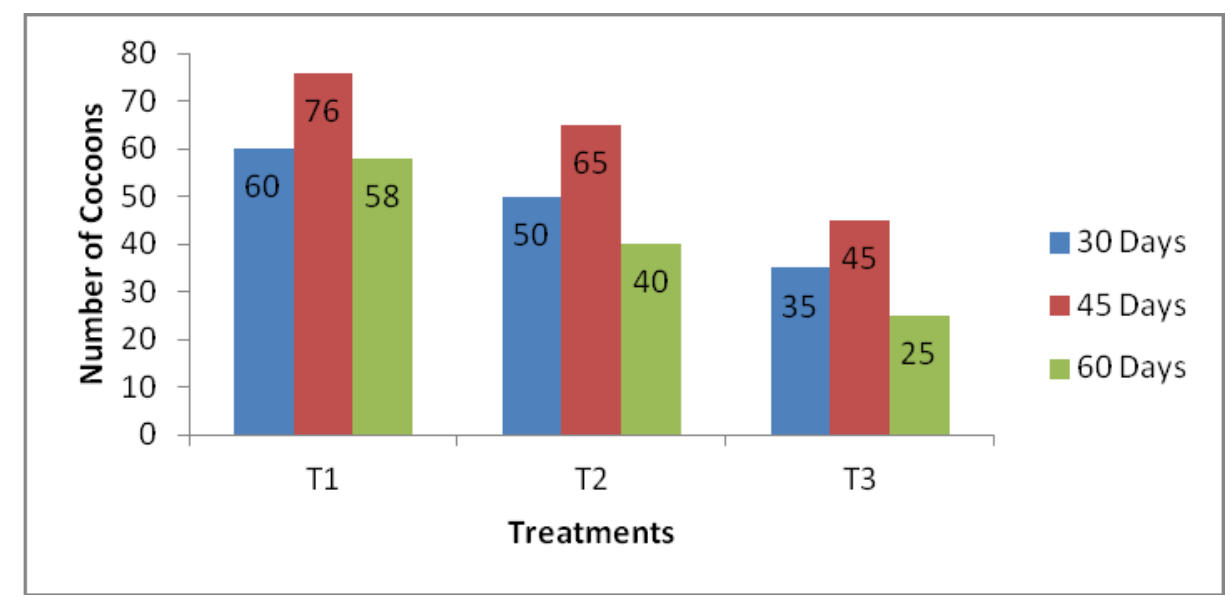

Fig. 2 Earthworm biomass in different treatments during vermicomposting

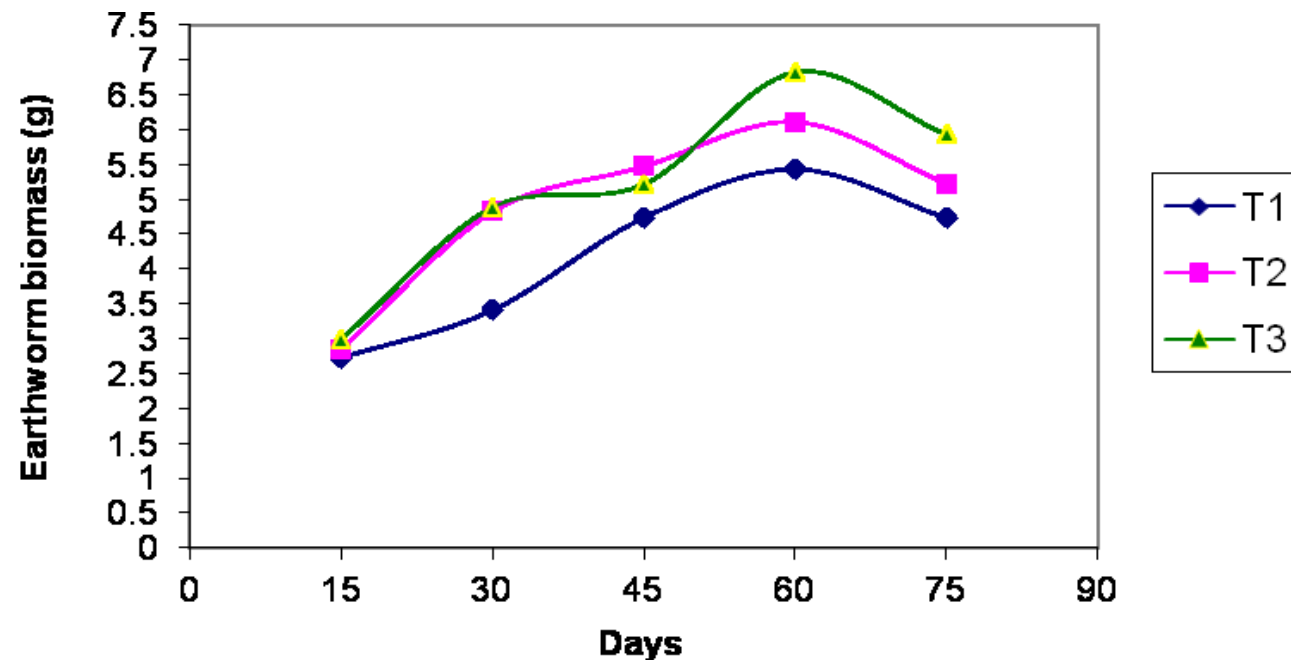


Total number of cocoons produced was maximum (76) in 25\%PMS $+75 \%$ BM and minimum (25) in $75 \%$ SPMS $+25 \%$ BM feed mixture (Fig 1). These results showed that BM amended with $25 \%$ and $50 \%$ PMS can be a suitable growth medium for E. eugeniae. These mixtures probably provide the earthworm with sufficient amount of easily metabolizable organic matter and non-assimilated carbohydrates that favours growth. The results suggested that higher proportions of PMS in bedding materials were not suitable for cocoon production. Production of cocoons in different feed mixtures can be related to the biochemical quality of the feed, which was one of the most important factors [38].

\section{Conclusion}

Vermiconversion paper mill sludge with bedding materials (cow dung, pig waste and water hyacinth) and E.eugeniae can solve the problem of disposal of this phytotoxic sludge by converting it into a nutrient rich supplement for plants in a short span of time ( 80 days).The final vermicomposts were homogenous, rich in important plant nutrients $\mathrm{N}, \mathrm{P}, \mathrm{K}, \mathrm{Fe}, \mathrm{Zn}, \mathrm{Cu}$ and $\mathrm{Mn}$ which indicated their agricultural value as a soil conditioner. These results also indicated the economic utilization of paper mill sludge mixed with bedding materials which may be very important to achieve sustainable development. Earthworm cocoon production performance was excellent in bedding those contained with lower proportions of paper mill sludge e.g. $T_{1}$ and $\mathrm{T}_{2}$, which suggests that paper mill sludge can retard the potentials of composting earthworms if applied at a higher rate in vermibeds. Thus the present experimental data provides a sound basis that vermicomposting is a suitable technology for the conversion of paper mill sludge into organic fertilizer and clearly demonstrates that the conversion of paper mill sludge with bedding materials into vermicompost may not only reduce the burden of synthetic fertilizers but also acts as a good soil conditioners and a source of plant nutrients in agriculture.

\section{Acknowledgements}

Author is highly thankful to University Grants Commission-RGNF, New Delhi (India) for providing financial assistance in the form of Junior Research Fellowship to conduct this work. And also the authors thank the principal, Periyar E.V.R College (Autonomous), Tiruchirappalli, Tamil Nadu, India for the encouragement and providing facilities for the study.

\section{References}

[1]. A. Kaur, J. Singh, A. P. Vig, S.S. Dhaliwal, and P.J. Rup, Cocomposting with and without Eisenia fetida for conversion of toxic paper mill sludge into soil conditioner, Bioresour. Technol. 101, 2010, 8192-8198.

[2]. K.C. Ashok, State of Art Report on Vermicomposting in India. Council for Advancement of People Action and Rural Technology (CPART), New Delhi, p. 60, 1994.

[3]. R. D. Kale, K. Bano, and R. V. Krishnamoorthy, Potential of Perionyx excavatus for utilizing organic wastes, Pedobiologia 23,1982, 419-425.

[4]. R. Hartenstein, E. F. Neuhauser, and D. L. Kaplan, Reproductive potential of earthworms Eisenia fetida, Oecologia 43, 1979, $329-340$

[5]. D. Mackenzie, Where earthworms fear to bread. New Scientist, 1991, 31-34.

[6]. P. Lavelle, I. Barois, A. Martin, Z. Zaidi, and Schaefer, Management of earthworm population in agro-ecosystem. In: Charholm, M., Berystrom, L. (Eds.), A Possible Way to Maintain Soil Quality and Ecology of Arabie Land, Kluwer Academic publishers, 1989, 109-122.

[7]. D. J. Murphy, Earthworms in Australia. Hyland House Publishing Pty Ltd., Victoria, 1993, (112pp.)

[8]. S. A. Ismail, Earthworms in soil fertility management. In: Thampan, P.K. (Ed.), Organic Agriculture. Peekay Tree Crops Development Foundation, Cochin, India, 1995 pp. 77-100.

[9]. C. A. Edwards, J. Dominguez, and E.F, Neuhauser, Growth and reproduction of Perionyx excavatus (Perr.) (Megascolecidae) as factors in organic waste management, Biology and Fertility of Soils 27, 1998, 155-161.

[10]. P Kaushik, Y. K. Yadav, N. Dilbaghi, and V. K. Garg, Enrichment of vermicomposts prepared from cow dung spiked solid textile mill sludge using nitrogen fixing and phosphate solubilizing bacteria, Environmentalist 28, 2008, $283-287$.

[11]. M. Aira, F. Monroy, and J. Dominguez, Earthworms strongly modify microbial biomass and activity triggering enzymatic activities during vermicomposting independently of the application rates of pig slurry, Sci. Total Environ. 385, $2007,252-261$.

[12]. J. Singh, A. Kaur, A.P. Vig, and P.J. Rup, Role of Eisenia fetida in rapid recycling of nutrients from bio sludge of beverage industry, Ecotoxicol. Environ. Saf. 73, 2010, 430-435.

[13]. C. Elvira, L. Sampedro, E. Benitez, and R. Nogales, Vermicomposting of sludges from paper mill and dairy industries with Eisenia andrei: a pilot scale study, Bioresour. Technol. 63, 1998, 205-211.

[14]. V.K. Garg, and P. Kaushik, Vermistabilization of textile mill sludge spiked with poultry droppings by an epigeic earthworm Eisenia fetida, Bioresour, Technol. 96, 2005, 1063-1071.

[15]. S. Suthar, Potential utilization of guar gum industrial waste in vermicompost production, Bioresour. Technol. 97, $2006,2474-2477$.

[16]. B. Sen, T.S. Chandra, Cemolytic and solid-state spectroscopic evaluation of organic matter transformation during vermicomposting of sugar industry wastes, Bioresour. Technol. 98, 2007, 1680-1683.

[17]. S. Suthar, and S. Singh, S., Vermicomposting of domesticwaste by using two epigeic earthworms (Perionyx excavatus and Perionyx sansibaricus), Int. J. Environ. Sci. Tech. 5 (1), 2008, 99-106.

[18]. B. Ravindran, S.L. Dinesh, L.J. Kennedy, G. Sekaran, Vermicomposting of solid waste generated from leather industries using epigeic earthworm Eisenia fetida, Appl. Biochem. Biotechnol. 151, 2008, 480-488.

[19]. S. Suthar, Recycling of agro-industrial sludge through vermitechnology, Ecol. Eng. 36, 2010, 1028-1036.

[20]. S. Hait, and V. Tare, Optimizing vermistabilization of waste activated sludge using vermicompost as bulking material. Waste Manage. 31 2011, 502-511. 
[21]. R. Ravindran, and G. Sekaran, Bacterial composting of animal fleshing generated from tannery industries, Waste Manage. 30, 2011, 2622-2630.

[22]. Negi, and S. Suthar, Vermistabilization of paper mill wastewater sludge using Eisenia fetida. Bioresour, Technol.128, 2013, $193-198$.

[23]. J. A. Walkey, J. A. Black, Estimation of organic carbon by the chromic acid titration method. Soil Sci. 37, 1934, 29-31.

[24]. M. L. Jackson, Soil Chemical Analysis. Prentice Hall of India, New Delhi, 1975.

[25]. S. R. Olsen, C.V. Cole, F. S. Watanabe, and L. A. Dean, Estimation of available phosphorus in soils by extraction with sodium bicarbonate, Circ. US Dept. Agric, 1954, p. 939.

[26]. R. R. Simard, Ammonium acetate extractable elements. In: Martin, R., Carter, S. (Eds.), Soil Sampling and Methods of Analysis, Lewis Publisher, FL, USA, 1993, pp. 39-43.

[27]. R. Gupta, P. K. Mutiyar, N. K. Rawat, M. S. Saini, and V.K. Garg, Development of a water hyacinth based vermireactor using an epigeic earthworm E. fetida, Bioresour, Technol. 98, 2007 2605-2610.

[28]. S. Suthar Vermicomposting of vegetable-market solid waste using Eisenia fetida: impact of bulking material on earthworm growth and decomposition rate, Ecol. Eng. 35, 2009, 914-920.

[29]. H, Deka, S, Deka, C. K, Baruah, J, Das, S, Hoque, H, Sarma, and N, S, Sarma S Vermicomposting potentiality of Perionyx excavatus for recycling of waste biomass of java citronella-An aromatic oil yielding plant. Bioresource Technol. 102, 2011, 1121211217.

[30]. M. Aira, F. Monroy, and J. Dominguez, Eisenia fetida (Oligochaeta, Lumbricidae) modifies the structure and physiological capabilities of microbial communities improving carbon mineralization during vermicomposting of pig manure, Microbial Ecol. 54, 2007, 662-671.

[31]. G. Tripathi, P. Bhardwaj, Decomposition of kitchen waste amended with cow manure using epigeic species (Eisenia fetida) and an anecic species (Lampito mauritii), Bioresour. Technol. 92, 2004, 215-218.

[32]. E. Benitez, R. Nogales, C. Elvira, G. Masciandaro, and B. Ceccanti, Enzyme activities as indicators of the stabilization of sewage sludge composting with Eisenia fetida, Biores, Technol. 67, 1999, 297-303.

[33]. S.S. Battacharya, and G. Chattopadhyay, Transformation of nitrogen during vermicomposting of flyash. Waste Manage.Res., 22, 2004, 488-491.

[34]. K. E. Lee, Some trends opportunities in earthworm research or: darwin's children, 1992.

[35]. S. Suthar, Bioconversion of post harvest crop residues and cattle shed manure into value-added products using earthworm Eudrilus eugeniae Kinberg. Ecol. Eng. 32, 2008, 206-214.

[36]. E.F, Neuhauser, R.C, Loehr, M.R, Malecki, The potential of earthworms for managing sewage sludge. In: Edwards, C.A., Neuhauser, E.F. (Eds.), Earthworms in Waste and Environmental Management. SPB Academic Publishing, The Hague, pp. 9-20, 1988.

[37]. K.R. Butt, Utilization of solid paper mill sludge and spent brewery yeast as a feed for soil-dwelling earthworms. Biores. Technol. 44, 1993, 105-107.

[38]. F. M. Flack, and R. Hartenstein. 1984. Growth of the earthworm Eisenia fetida on microorganisms and cellulose. Soil Biol. Biochem. 16, 1984, 491-495. 